\title{
SURVEI MAGNETOTELURIK DAN TDEM DAERAH PANAS BUMI KADIDIA - KADIDIA SELATAN, KABUPATEN SIGI, PROVINSI SULAWESI TENGAH
}

\author{
Oleh : \\ Ahmad Zarkasyi dan Nizar Muhamad Nurdin \\ Kelompok Penyelidikan Bawah Permukaan - Pusat Sumber Daya Geologi
}

\begin{abstract}
ABSTRAK
Daerah Kadidia merupakan salah satu daerah berpotensi panas bumi di Sulawesi Tengah yang ditandai dengan manifestasi panas bumi berupa mata air panas yang tersebar di berbagai daerah dengan temperatur $40,4-98,8{ }^{\circ} \mathrm{C}$. Penelitian panas bumi sudah dimulai sejak tahun 2012 hingga tahun 2014, survei magnetotelurik (MT) dan TDEM merupakan tindak lanjut dari survei terpadu (geologi, geokimia, dan geofisika) untuk mengcover potensi panas bumi. Hasil MT menunjukkan sebaran tahanan jenis rendah $(<40 \mathrm{Ohm}-\mathrm{m})$ pada kedalaman 1000-1500 meter, tahanan jenis rendah ini diperkirakan sebagai lapisan yang berfungsi sebagai batuan penudung dan di bawah lapisan ini diperkirakan merupakan lapisan yang berfungsi sebagai reservoir panas bumi. Daerah prospek panas bumi Kadidia dan Kadidia Selatan meliputi zona depresi Kadidia disekitar pemunculan manifestasi. Luas daerah prospek untuk Kadida dari hasil kompilasi adalah sekitar $16 \mathrm{~km}^{2}$ dan untuk Kadidia Selatan memilki luas sekitar $5 \mathrm{~km} 2$.
\end{abstract}

Kata kunci : magnetotelurik, panas bumi, Kadidia, Sulawesi Tengah

\section{PENDAHULUAN}

Daerah panas bumi Kadidia dan Kadidia Selatan berada di Kabupaten Sigi, Provinsi Sulawesi Tengah. Keberadaan sistem panas bumi di daerah ini ditandai dengan dengan manifestasi panas bumi berupa alterasi batuan, tanah panas dan mata air panas yang tersebar di berbagai daerah dengan temperatur berkisar antara 40,4 - $98,8^{\circ} \mathrm{C}$. Survei MT dan TDEM bertujuan untuk mengungkap serta mencover daerah potensi sesuai sistem panas bumi yang berkembang di Kadidia dan Kadidia Selatan.

Stratigrafi daerah penyelidikan dibagi dua yaitu daerah Kadidia dan Kadidia Selatan. Stratigrafi ini berdasarkan hasil pemetaan di lapangan, juga didukung oleh data analisis citra landsat, dengan memperhatikan prinsip litostratigrafi, serta hubungan relatif antara masing-masing satuan batuan. Daerah Kadidia (Gambar 2) didominasi oleh batuan produk plutonik berkomposisi granitik yang tersebar cukup luas serta endapan-endapan permukaan. Daerah Kadidia Selatan (Gambar 3) pada umumnya tersusun oleh batuan plutonik dan sedimen dan sebagian kecil batuan vulkanik. Berdasarkan sejarah geologinya, daerah Kadidia Selatan termasuk ke dalam Mandala Sulawesi Tengah bagian Timur yang tersusun oleh batuan tertua berupa produk vulkanik Tersier dengan jenis lava dan breksi andesit (Tlt) produk gunung Towingkoloe, yang ditindih oleh produk sedimentasi berupa batupasir (Tbp) dan konglomerat (Tkl). Seiring terjadinya obduksi antara mandala Sulawesi bagian barat dengan Mandala Sulawesi tengah bagian timur akibat pergerakan sesar sorong menghasilkan produk plutonik granit yang berumur lebih muda pada Akhir Tersier (Tg). Selanjutnya terbentuk endapan molase berupa koluvium (Qk) yang merupakan produk rework dari batuan Tersier.

Daerah penyelidikan termasuk kedalam Mandala Sulawesi Tengah bagian Timur yang tersusun oleh batuan tertua berupa produk vulkanik Tersier dengan jenis lava dan breksi andesit (Tlt) produk gunung Towingkoloe, yang ditindih oleh produk sedimentasi berupa batupasir (Tbp) dan konglomerat (Tkl). Seiring terjadinya obduksi antara mandala 
sulawesi bagian barat dengan mandala sulawesi tengah bagian timur akibat pergerakan sesar sorong menghasilkan produk plutonik granit yang berumur lebih muda pada Akhir Tersier (Tg). Selanjutnya terbentuk endapan molase berupa kolovium (Qk) yang merupakan produk rework dari batuan Tersier.

Berdasarkan data tektonisme daerah penyelidikan menunjukkan pengaruh yang cukup kuat dari pola sesar mendatar mengiri Palu - Koro yang berarah baratlaut - tenggara beserta antitetiknya yang berarah barat - timur. Keberadaan sesar besar basemen seperti sesar Koala Rawa yang menerus ke bagian baratlaut desa Rahmat dipotong oleh sesar periode ke tiga yang berarah hampir utara - selatan, dan diduga sesar dengan arah tersebut merupakan pembentuk zona permeabel pembentuk aktivitas hidrotermal yang meloloskan fluida panas ke permukaan.

Sesar yang berarah baratlaut tenggara ditunjukkan oleh sesar Koala Rawa sebagai pengontrol manifestasi panas bumi di Sungai Koala Rawa, di bagian utaranya terbentuk sesar Noki, sesar Towingkoloe dan sesar Kumamora.

Sesar yang berarah barat daya timur laut ditunjukkan oleh sesar Dongi, sesar Lindu dan sesar Kadidia yang juga memfasilitasi munculnya manifestasi di sekitar Sungai Koala Rawa. Sesar yang berarah utara selatan ditunjukkan oleh sesar Rahmat dan komplek Kumamora sedangkan sesar yang berara Barat timur ditunjukkan oleh sesar Bulili dan sesar Gangga dimana kenampakan dilapangan berupa gawir sesar dan kelurusan sungai.

Pada anomali bouger sisa liniasi struktur yang arahnya sama dengan peta geologi yaitu baratdaya-timur laut dan 1 struktur berarah hampir utara selatan. Anomali rendah $<0 \mathrm{mgal}$ berada di tengah-tenggah area survei mengisi zona depresi. Anomali tinggi $>4$ mgal berada di sekitar manifestasi Kadidia dan manifestasi Sejahtera. Hasil survei geomagnet, anomali magnet total UWC 300, anomali magnet rendah berada di antara manifestasi Kadida dan Sejahtera. Keberadaan anomali magnet rendah menunjukan adanya zona demagntesasi di sekitar manifestasi kadidia dan sejahtera. Zona demagnetisasi ini di perkirakan merupakan respon dari batuan yang teralterasi oleh aktifitas hidrothermal.

\section{METODE DAN TEORI}

Metode Survei MT

Metode survei magnetotellurik pada daerah panas bumi dilakukan dengan tahapan studi literatur, persiapan kerja lapangan (kalibrasi peralatan) desain survei, akuisisi, pengolahan dan pemodelan data.

Berdasarkan hasil terdahulu tentang sistem panas bumi daerah Kadidia Kadida Selatan maka titik pengukuran MT didesain sehingga hasil yang diharapkan tercapai. Akuisisi data pengukuran menggunakan Zonge System dengan rentang frekuensi terendah $0,01 \mathrm{~Hz}$. Data hasil pengukuran diproses dengan menggunakan algoritma Robust. Kemudian data dikoreksi, editing dan dianalisis EM strike (rotasi).

Penentuan arah rotasi Dalam pemrosesan data MT menggunakan metode tensor impedansi untuk kuantitatifnya dan arah struktur geologi untuk kualitatifnya. Setelah proses rotasi dan editing, data yang mengalami shifting dikoreksi dengan menggunakan data TDEM. Data yang terkoreksi ini yang selanjutnya digunakan untuk pemodelan 2 dimensi.

\section{Teori Dasar MT dan TDEM}

Metode MT adalah salah satu metode geofisika yang memanfaatkan gelombang elektromagnetik. Metode ini mengukur respon bumi dalam besaran medan listrik (E) dan medan magnet $(\mathrm{H})$ terhadap medan elektromagnetik (EM) alam. 
Respon tersebut berupa komponen horizontal medan magnet dan listrik bumi yang diukur pada permukaan bumi pada posisi tertentu.

Tahanan jenis dari metode ini dihitung berdasarkan perbandingan besarnya medan listrik dan medan magnet yang dikenal dengan persamaan Cagniard. Persamaan ini dihasilkan dari persamaan Maxwell dengan asumsi gelombang bidang.

$$
\rho_{a}=\frac{1}{5} f \times\left|\frac{E}{H}\right|^{2}
$$

\section{Dimana}

$\rho_{\mathrm{a}}$ : tahanan jenis semu (Ohm-m)

$f$ : frekuensi $(\mathrm{Hz})$

E : Besarnya medan listrik $(\mathrm{mV} / \mathrm{km})$

$\mathrm{H}$ : Besarnya medan magnet (nT)

Tahanan jenis semu terdiri dari dua kurva seperti Rho $\mathrm{xy}_{\mathrm{y}}$ dan $\mathrm{Rho}_{\mathrm{yx}}$, kemudian dirotasi terhadap sumbu utama, bisa kedalam TE mode (medan listrik sejajar dengan strike) atau TM Mode (medan listrik tegak lurus strike).

Penetrasi kedalaman efektif dapat ditentukan dengan menggunakan persamaan di bawah ini :

$\delta=503 \times(\rho / f)^{1 / 2}$

Dimana

$\delta \quad$ : penetrasi kedalaman efektif $(\mathrm{m})$

$\rho \quad$ : tahanan jenis semu (Ohm-m)

f $\quad$ : frekuensi $(\mathrm{Hz})$

Ketika tahanan jenis berubah terhadap kedalaman, maka tahanan jenis semu akan berubah terhadap frekuensi, karena frekuensi tinggi tidak memiliki penetrasi yang cukup dalam, sedangkan frekuensi rendah memiliki penetrasi lebih dalam. Hal ini menunjukkan bahwa struktur tahanan jenis dari zona dangkal sampai ke zona dalam dapat dianalisis berdasarkan tinggi atau rendahnya frekuensi.

Skin depth sebagai fungsi dari frekuensi dan tahanan jenis dapat ditentukan dari persamaan berikut.

$$
\delta=\left(\frac{2}{\omega \mu \sigma}\right)^{\frac{1}{2}}=503 \sqrt{\frac{\rho}{f}}
$$

Dimana

$$
\begin{array}{ll}
\delta & : \text { skin depth }(\mathrm{m}) \\
\omega & :(=2 \pi \mathrm{f}) \text { frekuensi sudut } \\
\sigma & : \text { konduktivitas }(\mathrm{S} / \mathrm{m}) \\
\mu & : \text { permeabilitas magnet }(\mathrm{H} / \mathrm{m}) \\
\rho & : \text { tahanan jenis semu }(\mathrm{Ohm}-\mathrm{m}) \\
\mathrm{f} & : \text { frekuensi }(\mathrm{Hz})
\end{array}
$$

Metode TDEM (Time Domain Electro Magnetic) atau kadang disebut juga TEM (Transient Electro Magnetic) adalah salah satu metode geofisika yang memanfaatkan medan elektromagnetik untuk mengetahui struktur tahanan jenis bawah permukaan. Metode ini menggunakan sumber buatan dengan mengukur peluruhan tegangan transient sebagai fungsi waktu.

$$
V(t, r)=I_{0} \frac{C\left(\mu_{0} \sigma r^{2}\right)^{3 / 2}}{10 \pi^{1 / 2} t^{5 / 2}}
$$

dimana, $C=A_{r} N_{r} A_{S} N_{S} \frac{\mu_{0}}{2 \pi r^{3}}$, dan

$A_{r}=$ Luas area receiver coil $\left(\mathrm{m}^{2}\right)$

$N_{r}=$ Jumlah perputaran didalam receiver coil

$A_{s}=$ Luas area dari transmitting loop $\left(\mathrm{m}^{2}\right)$

$N_{S}=$ Jumlah perputaran didalam transmitter loop

$t_{r}=$ Waktu yang berjalan setelah arus pada transmitter dimatikan

$\mu_{0}=$ Permeabilitas magnetik $\left(\frac{\text { henry }}{m}\right)$

$V(t, r)=$ Tegangan transien

$r=$ Jari-jari dari transmitter loop $(m)$

$I_{0}=$ Arus pada transmitting loop $(A)$ 
Dengan mengsubtitusi $\sigma=\frac{1}{\rho}$, pada persamaan diatas, sehingga menghasilkan nilai tahanan jenis sebagai berikut:

$\rho_{a}=\frac{\mu_{0}}{4 \pi}\left[\frac{2 I_{0} A_{r} N_{r} A_{S} N_{S}}{5 t^{5 / 2} V(t, r)}\right]^{3 / 2}$

Hubungan ini mendefinisikan bahwa nilai tahanan jenis semu terhadap lamanya waktu yang berjalan setelah arus dimatikan.

\section{HASIL PENYELIDIKAN}

Jumlah titik MT sebanyak 36 titik dan TDEM 18 titik dengan jarak antar titik ukur berkisar 500-1500 meter (Gambar 4). Sebaran titik melingkupi mata air panas yang diduga sebagai area keprospekan panas bumi. Kualitas data mayoritas bagus hingga frekuensi sekitar $0,01 \mathrm{~Hz}$. Sedangkan frekuensi $<0,01 \mathrm{~Hz}$ kualitas data yang peroleh mulai mendapatkan noise. Pada beberapa data terdapat shifting yang akan terkoreksi oleh data TDEM.

Hasil pengolahan data berupa nilai tahanan jenis yang ditampilkan dalam bentuk lateral maupun vertikal. Selain model tahanan jenis ditampilkan pula tahanan jenis semu invarian yang merupakan tahanan jenis hasil penggabungan $\mathrm{rho}_{\mathrm{xy}}$ dan $\mathrm{rho}_{\mathrm{yx}}$ sebagai acuan awal atau pengontrol hasil pemodelanannya.

\section{Tahanan Jenis}

\section{Pemodelan tahanan jenis} dihasilkan menggunakan teknik inversi 2D yang dilakukan pada data pengukuran yang telah dianalisis, editing dan koreksi statik. Hasil pemodelan berupa nilai tahanan jenis dan posisi kedalamannya. Nilai tahanan jenis hasil pemodelan ditampilkan secara vertikal dalam bentuk penampang dan lateral vertikal dalam bentuk peta sebaran.

Penampang dan sebaran tahanan jenis yang dicuplik pada berbagai Pusat Sumber Daya Geologi - Badan Geologi - Kementrian Energi dan Sumber Daya Mineral

kedalaman (Gambar 6 dan Gambar 7) ditampilkan agar mempermudah interpretasi tentang keprospekan dan struktur penyusun sistem panas yang berkembang di daerah Kadidia dan Kadidia Selatan. Kadidia - Kadidia Selatan berkorelasi dengan morfologinya. Kemiripan ini berdasarkan hasil pemetaan geologi permukaan, Survei Terpadu PSDG 2012 dan 2014. Geomorfologi daerah KadidiaKadidia selatan dapat dibedakan menjadi morfologi perbukitan di bagian utara dan selatan yang keduanya tersusun oleh batuan beku berupa granit. Morfologi pedataran terbentuk di bagian tengah sebagai zona depresi akibat adanya sesar normal di sisi utara dan selatan yang tersusun oleh endapan danau dan batuan alluvial dan di sisi paling selatan terdapat sebuah danau dengan area yang cukup luas. Kadidia dan Kadidia Selatan ini berpola sesuai litologi dan morfologi yang terbentuk di daerah ini. Sebaran tahanan jenis rendah dengan nilai $<40 \mathrm{Ohmm}$ mengisi zona depresi di bagian tengah dan daerah bagian selatan dekat dengan Danau Lindu yang diperkirakan sebagai respon batuan sedimen. Sedangkan area perbukitan ditempati oleh nilai tahanan jenis tinggi >200 Ohmm sebagai respon batuan beku. Pola ini terbentuk sampai dengan kedalaman 1000 meter. Jika merujuk informasi geologi, maka pola yang terbentuk sampai kedalaman 1000 meter ini sangat sesuai dengan litologinya. Batuan sedimen yang mengisi zona depresi memilki nilai rendah dan batuan beku berupa granit bertahanan jenis tinggi termodelkan di morfologi perbukitan. terjadi di bagian tengah, antara morfologi pedataran dan perbukitan. Kerapatan kontur dan liniasinya mengindikasikan adanya zona sesar berarah baratlaut-

Litologi batuan penyusun daerah

Sebaran tahanan jenis di daerah

Gradasi nilai tahanan jenis rapat 
tenggara yang membentuk depresi Kadidia. Zona batas depresi ini terlihat jelas pada penampang tahanan jenis yang memotong litologi alluvial di pedataran dan granit di perbukitan.

Perubahan nilai tahanan jenis yang semakin tinggi dengan bertambah kedalaman mengindikasikan batuan yang semakin kompak dan segar. Dengan bertambah kedalaman, nilai tahanan jenis rendah yang mengisi zona depresi dan diinterpretasikan sebagai batuan alluvial dan endapan danau, luasnya semakin berkurang. Bahkan pada kedalaman 1250 meter, nilai tahanan jenis rendah hanya menempati area-area sekitar mata air panas. Hal ini menunjukkan pada kedalaman tersebut litologi batuan sudah mencapai basemen yaitu batuan beku. Sedangkan pada lokasi-lokasi sekitar mata air panas diduga sebagai zona anomali tahanan jenis yang terjadi akibat adanya fluida panas. Hal ini terlihat jelas juga pada penampang tahanan jenis (Gambar 7) dimana tahanan jenis mulai meninggi pada kedalaman sekitar 1000$1250 \mathrm{~m}$.

Area sekitar manifestasi panas bumi Sejahtera, Kadidia dan Koala Rawa berada pada zona sesar, seperti manifestasi Kadidia dan Sejahtera yang berada di batas zona depresi.di area-area tersebut tahanan jenis bernilai rendah $<25$ Ohmm dan konsisten termodelkan sampai ke kedalaman 1000-1500 meter kecuali area mata air panas Koala Rawa yang hanya sampai kedalaman 750 meter. Nilai tahanan jenis rendah tersebut diakibatkan adanya fluida panas dari sistem panas bumi yang mengubah lingkungan batuannya menjadi batuan teralterasi bersifat lempung. Interpretasi nilai rendah sebagai akibat batuan teralterasi ini bersifat ambigu, karena lingkungan batuan sekitarnya tersusun dari batuan sedimen yang juga memiliki nilai yang rendah. Hal berbeda dengan area mata air panas Koala Rawa, dimana batuan sekitarnya tersusun dari batuan beku sehingga tahanan jenis batuan selalu bernilai relatif lebih rendah dibanding sekitarnya.

Ambiguitas tahanan jenis rendah antara anomali akibat sistem panas bumi dengan batuan sedimen mulai tereliminasi di kedalaman. Mulai kedalaman 1000 sampai dengan 1500 meter, nilai tahanan jenis rendah tetap mengisi di sekitar area manifestasi air panas. Sedangkan area depresi bagaian lain sudah memilki nilai yang tinggi. Kondisi ini menjadi indikasi kuat, adanya pengaruh sistem panas bumi yang bekerja di area-area sekitar manifestasi.

\section{DISKUSI}

Hasil pemodelan magnetotelurik daerah Kadidia dan Kadidia Selatan (Gambar 6 dan 7) merupakan dua sistem panas bumi yang terpisah dibatasi oleh struktur geologi. Pada area Kadidia memperlihatkan adanya anomali tahanan jenis rendah (<25 ohmm) yang muncul di zona depresi di antara kemunculan mata air panas Kadidia dan Sejahtera pada lingkungan sedimen/alluvial. Anomali tersebut diduga merupakan batuan teralterasi oleh fluida panas sehingga nilai tahanan jenisnya menjadi lebih rendah dibandingkan lingkungan sekitarnya $(<50$ Ohmm). Batuan teralterasi dan bertahanan jenis rendah ini yang membentuk lapisan batuan yang bersifat kedap sehingga menahan fluida panas dari bawah. Lapisan ini mulai terdeteksi pada kedalaman 250 meter dan sampai dengan kedalaman sekitar 1000-1250 meter dengan luas yang bervariasi. Pada kedalaman 1250-1500 meter, lapisan bertahanan jenis rendah tidak ditemukan lagi dan diperkirakan pada kedalaman ini telah masuk zona reservoir atau tempat terakumulasi fluida panas dengan air dari permukaan. Lapisan reservoir ini berdasarkan MT memiliki nilai tahanan jenis tinggi $>100$ ohmm dan diduga tersusun dari batuan beku granit. 
Pada area Kadidia Selatan, nilai tahanan jenis rendah $<25$ terdeteksi hanya pada sekitar area-area manifestasi Koala Rawa. Pada kedalaman sekitar 500-750 meter, area sekitar manifestasi panas bumi tahanan jenisnya sudah mulai meninggi. Nilai tahanan jenis rendah $<25$ Ohmm di area ini seperti halnya di zona depresi merupakan batuan terlaterasi yang berfungsi sebagai lapisan penudung. Sedangkan nilai tahanan jenis yang mulai meninggi di kedalaman sekitar 500-750 diperkirakan sudah masuk zona resevoirnya.

\section{KESIMPULAN}

Daerah prospek panas bumi Kadidia berada zona depresi Kadidia melingkupi daerah pemunculan manifestasi Kadidia dan Sejahtera. Lapisan batuan penudung diperkirakan tersusun dari alluvial, endapan danau dan granit yang telah mengalami alterasi dengan tahanan jenis <25 Ohmm. Lapisan penudung terdeteksi sampai dengan kedalaman sekitar 1000 - 1250 meter. Lapisan reservoir diduga tersusun dari batuan granit yang telah terfrakturkan dengan tahanan jenis di atas 100 ohmm. Kedalaman puncak resevoir bervariasi sekitar 1250-1500 meter. Daerah prospek panas bumi Kadida memiliki luas sekitar $16 \mathrm{~km}^{2}$ dengan potensi panas sekitar 66 MWe.

Daerah prospek panas bumi Kadidia Selatan berada di bagian selatan dari perbukitan granit. Lapisan penudungnya berasal dari batuan granit yang yang telah teralterasi dengan nilai tahanan jenis $<25 \mathrm{Ohmm}$. lapisan resevoir diinisialisasi dengan tahanan jenis di atas 100 Ohmm. Kedalaman puncak resevoirnya berada pada kedalaman sekitar 500-750 meter. Daerah prospek panas bumi Kadidia Selatan memiliki luas sekitar $5 \mathrm{~km}^{2}$ dengan potensi panas sekitar $26 \mathrm{MWe}$.

\section{UCAPAN TERIMA KASIH}

Ucapan terima kasih tim penulis hantarkan kepada para staf Pusat Sumber Daya Geologi bidang panas bumi yang telah berperan serta dalam penulisan ini. Kegiatan diskusi terutama tentang informasi geologi daerah Kadidia dan Kadidia Selatan.

\section{DAFTAR PUSTAKA}

Burger, H.R., 1992, Exploration Geophysics of shallow Sub Surface, Prentice Hall.

Geothermal Departement, Basic Concept of Magnetotelluric Survey in Geothermal Fields., West Japan Engineerring Consultants, Inc.

Lawless, J., 1995, Guidebook: An Introduction to Geothermal System. Short course. Unocal Ltd. Jakarta

Sheriff, R. E., 1982, Encyclopedic Dictionary of Exploration Geophysics, Society of Exploration Geophysicists, Tulsa, Oklahoma.

Telford, W. M., Geldart, L. P., Sheriff, R. E., Keys, D. A., 1990, Applied Geophysics, Cambridge University Press, London.

Tim Survei Geofisika, 2010, Laporan Survei Geofisika Terpadu (Geolistrik, Magnet dan Gaya Berat) Daerah Panas Bumi Bora, Kabupaten Sigi, Provinsi Sulawesi Tengah, Pusat Sumber Daya Geologi, Kementrian Energi dan Sumber Daya Mineral Indonesia. (Unpubl. Report).

Tim Survei Terpadu (2012). Laporan Survei Terpadu Daerah Panas Bumi Kadidia, Kabupaten Sigi, Sulawesi Tengah, Pusat Sumber Daya Geologi, Kementrian Energi dan Sumber Daya Mineral Indonesia. (Unpubl. Report).

Tim Survei MT (2012). Laporan Survei Magnetotellurik Daerah Panas Bumi Kadidia, Kabupaten Sigi, Sulawesi Tengah, Pusat Sumber Daya 
Geologi, Kementrian Energi dan Sumber Daya Mineral Indonesia. (Unpubl. Report).

Tim Survei Terpadu (2014). Laporan Survei Terpadu Daerah Panas Bumi
Kadidia, Kabupaten Sigi, Sulawesi

Tengah, Pusat Sumber Daya

Geologi, Kementrian Energi dan

Sumber Daya Mineral Indonesia. (Unpubl. Report).

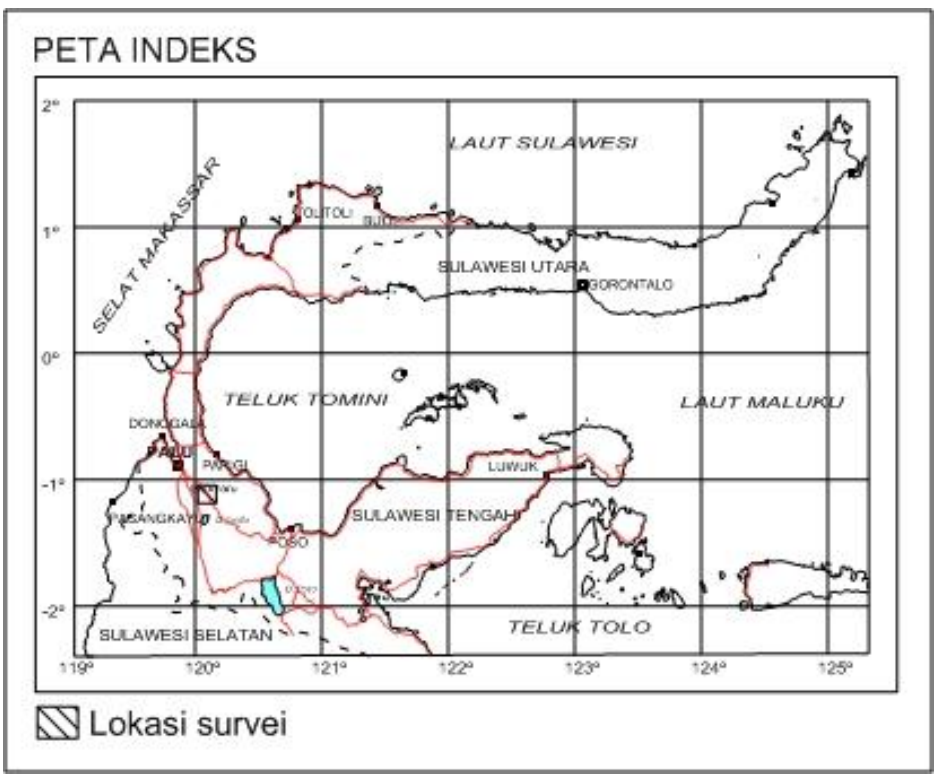

Gambar 1. Peta lokasi daerah survei MT dan TDEM Kadidia - Kadidia Selatan

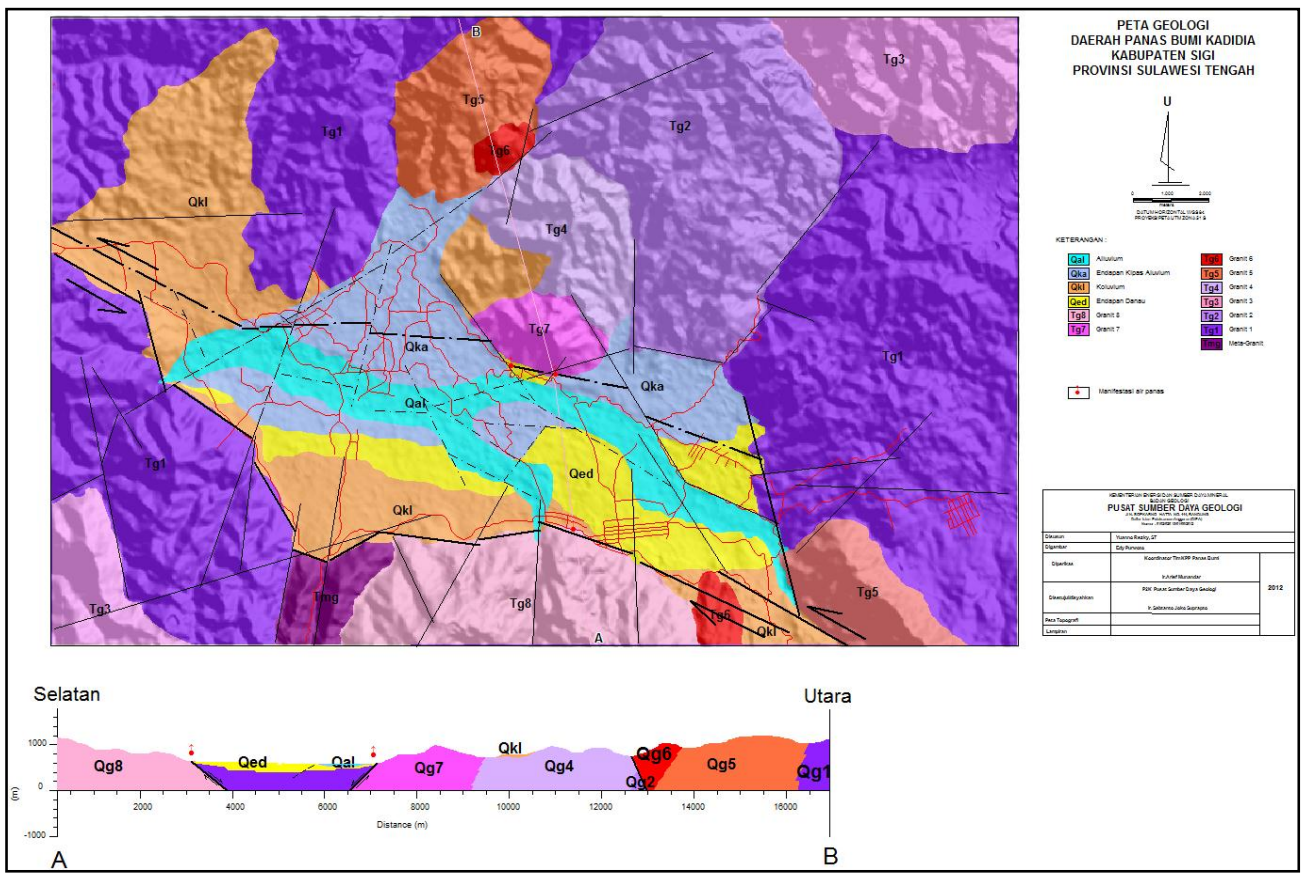

Gambar 2. Peta Geologi daerah Panas Bumi Kadidia 


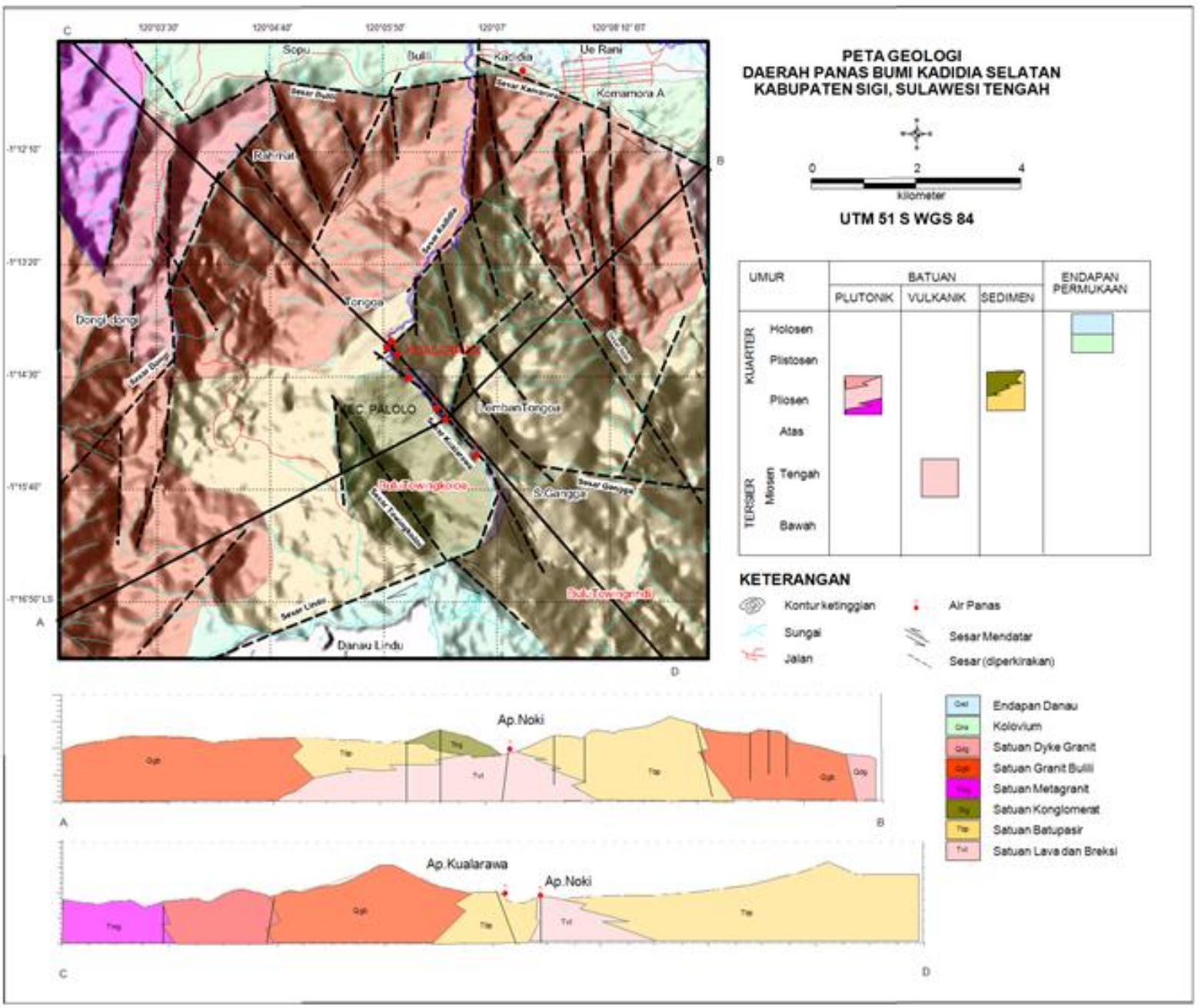

Gambar 3. Peta Geologi daerah Panas Bumi Kadidia Selatan

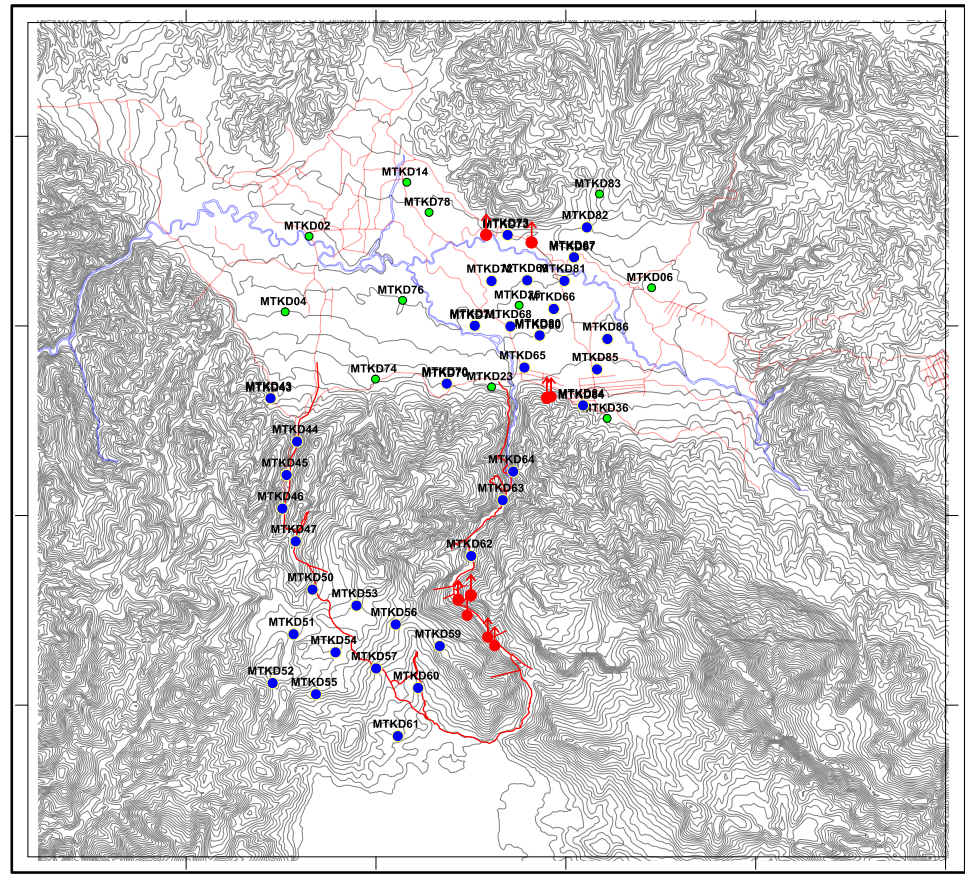

Gambar 4. Peta distribusi titik ukur MT dan TDEM daerah Kadidia Selatan

Pusat Sumber Daya Geologi - Badan Geologi - Kementrian Energi dan Sumber Daya Mineral Jalan Soekarno- Hatta No 444 Bandung Jawa Barat

Website: psdg.geologi.esdm.go.id 


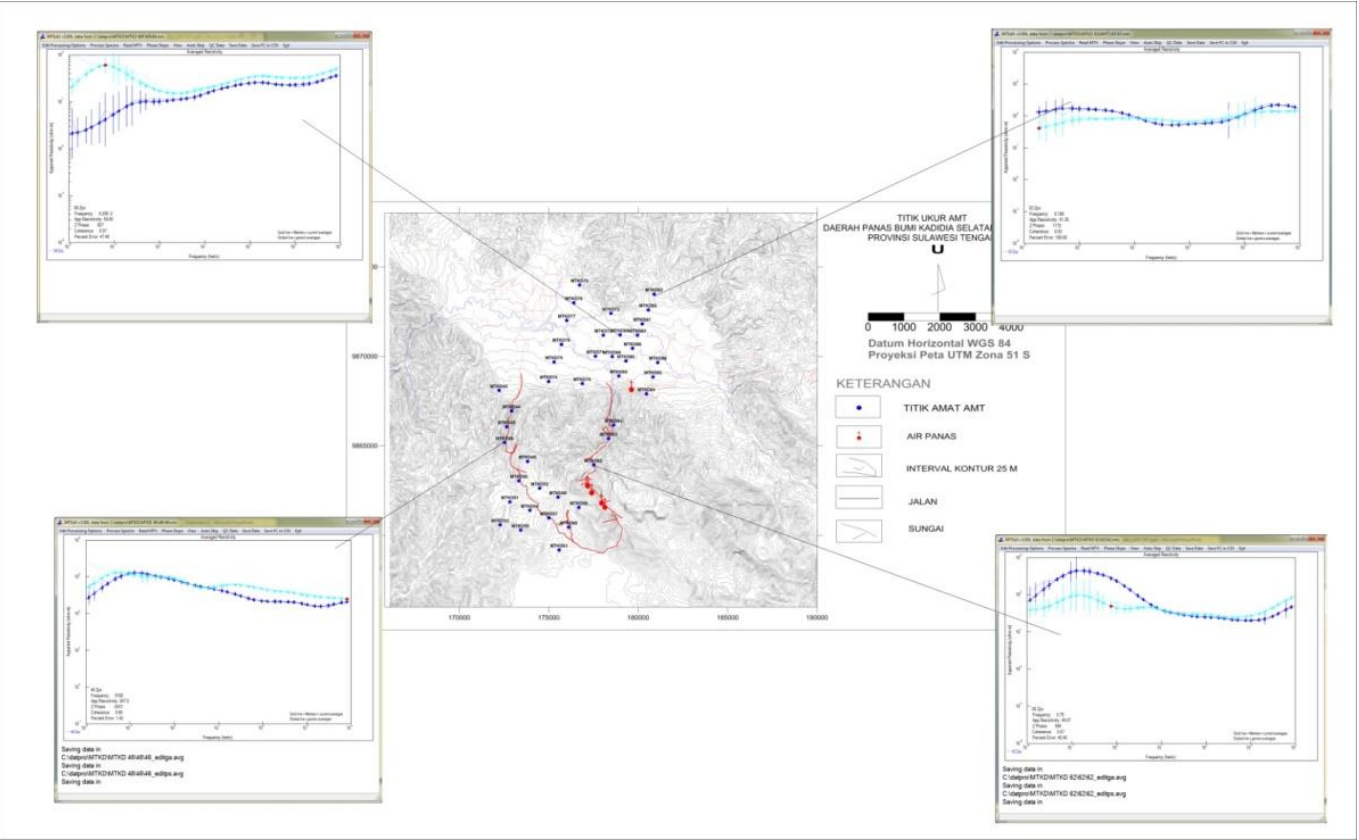

Gambar 5. Kurva hasil pengukuran MT daerah panas bumi Kadidia - Kadidia Selatan

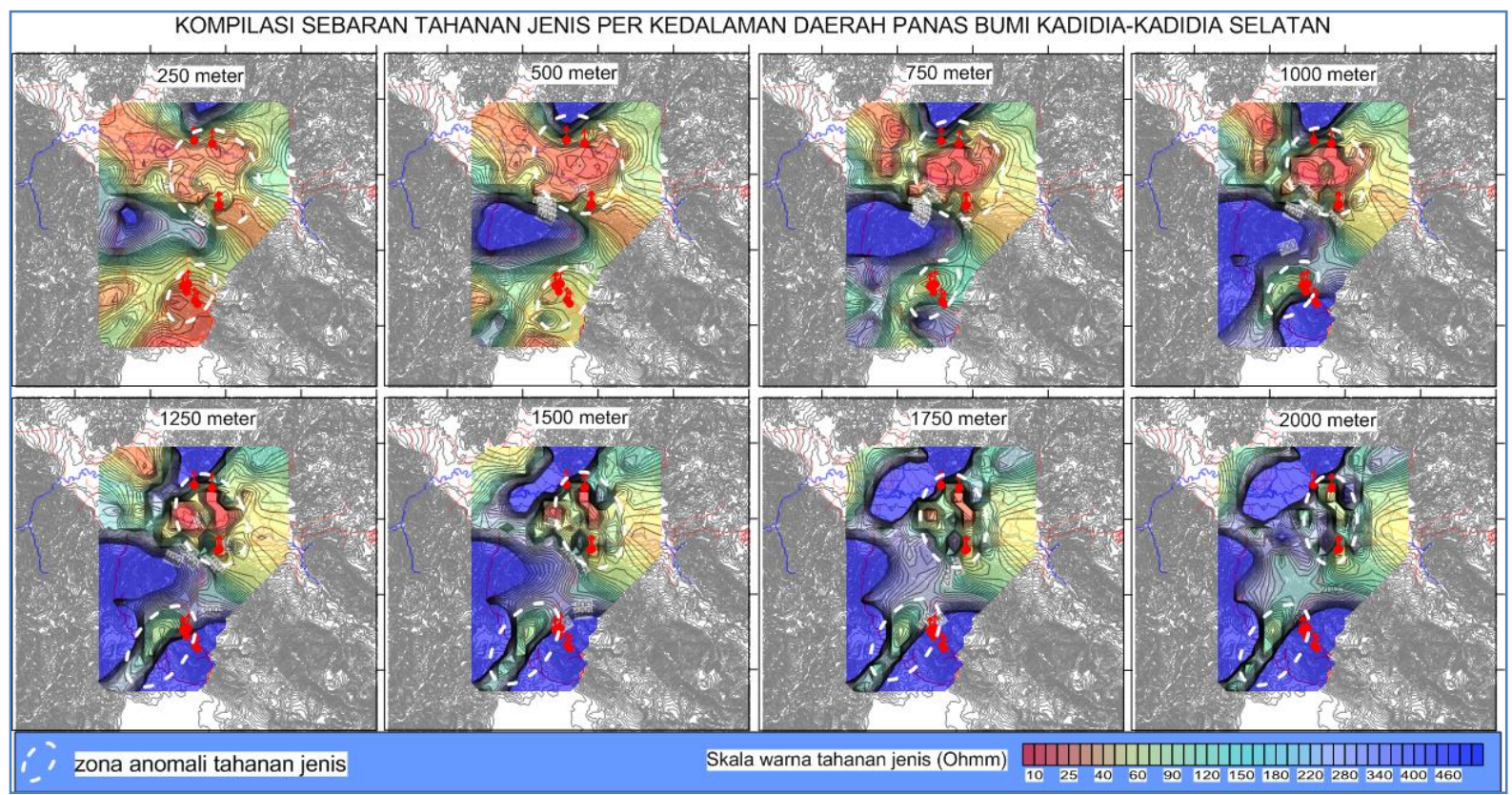

Gambar 6. Sebaran tahanan jenis per kedalaman daerah panas bumi Kadidia - Kadidia Selatan 


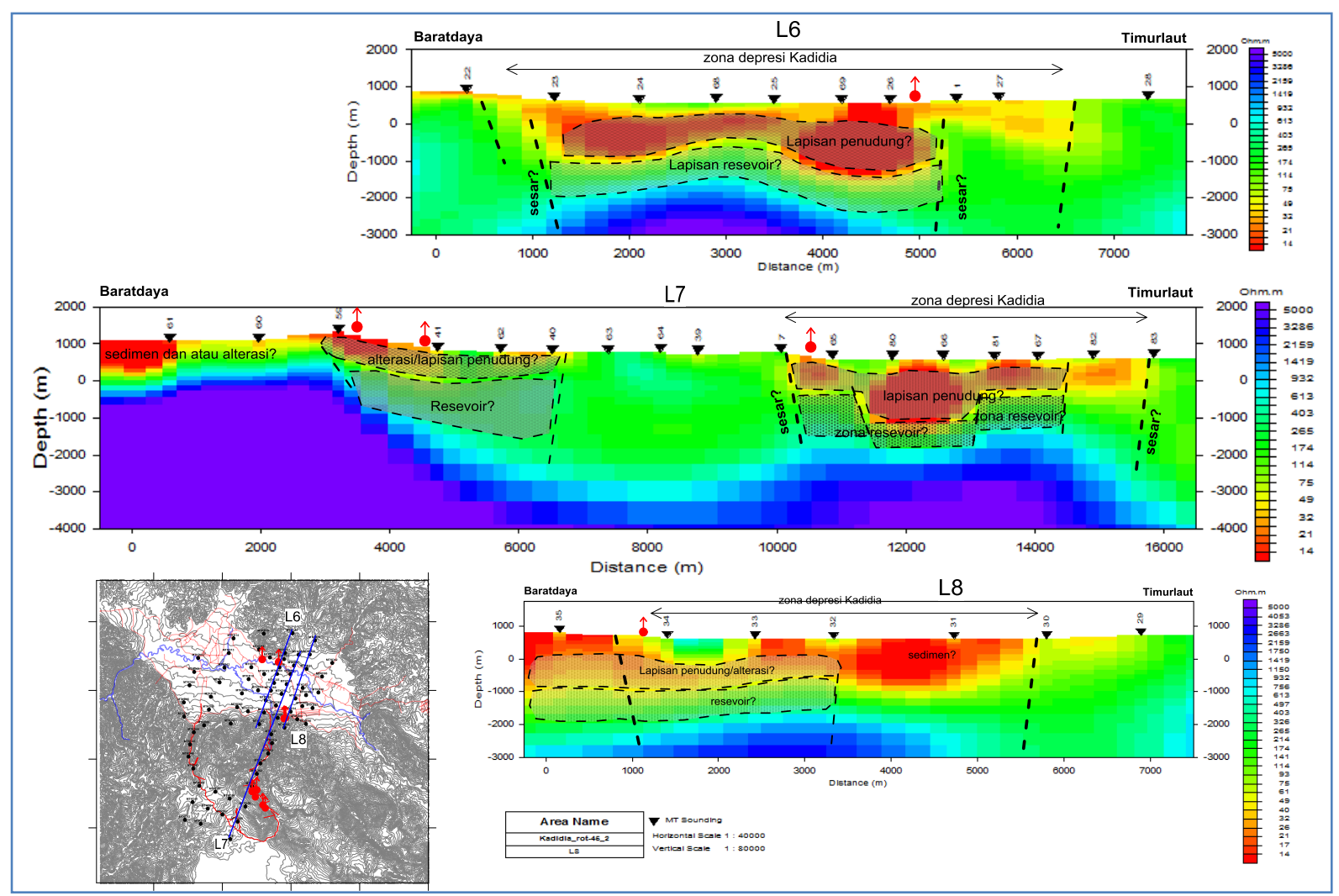

Gambar 7. Penampang tahanan jenis daerah panas bumi Kadidia - Kadidia Selatan 